\title{
Effectiveness, Risks and Prospects of Legal Regulation and Practical Functioning of Electronic Visas in Saudi Arabia and Ukraine
}

\author{
Yuriy Pyvovar ${ }^{1} \&$ Nizar Bandar ${ }^{2}$ \\ ${ }^{1}$ Constitutional and Administrative Law Department, Law Faculty, National Aviation University, Kyiv, Ukraine \\ ${ }^{2}$ Embassy of Ukraine in the Kingdom of Saudi Arabia, Riyadh, Kingdom of Saudi Arabia \\ Correspondence: Yuriy Pyvovar, Constitutional and Administrative Law Department, Law Faculty, National \\ Aviation University, Kyiv, Ukraine. E-mail: pyvovaryi@gmail.com
}

\author{
Received: April 6, 2020 \\ Accepted: April 30, $2020 \quad$ Online Published: May 25, 2020 \\ doi:10.5539/jpl.v13n2p101 \\ URL: https://doi.org/10.5539/jpl.v13n2p101
}

\begin{abstract}
The Electronic visa legislative regulation is one of the highest priorities in the country's migration, security and visa policies. The purpose of this study is to compare the legal aspects of visa policy making in the process of issuing electronic visas in Ukraine and in Saudi Arabia, and to identify the distinctive and common features of this type of visa, legislative features, practical aspects, taking into account the specific national legislation of these countries; elicit the disadvantages and perspectives of e-visa. Over a period of 3 months, about 100 Saudi and 20 Ukrainian respondents were interviewed to identify the pros and cons of existing e-visa regulations in both countries. As a results of the research, the hypothesis put forward regarding the fact that in the next 5-10 years, e-visas will almost completely replace the visa application for obtaining short-term visas through diplomatic institutions. It was established that this required the creation of a more simplified and faster way to obtain an e-visa, while not losing ground in matters of state security and migration. As a result of comparison it has been established that service of electronic visas in Ukraine was launched one and a half years earlier than in Saudi Arabia, which enabled her to secure more completely the situation and take into account the nuances of the legislative level; the amount of the visa fee for applying for an electronic visa established by Ukraine and Saudi Arabia is acceptable for most applicants, although in comparison with a visa-free or one-time electronic authorization fee for several years, these amounts are large.
\end{abstract}

Keywords: electronic visa, immigration law, Kingdom of Saudi Arabia, visa policy, visa requirements

\section{Introduction}

\subsection{Introduce the Problem}

The visa policy of any country is closely intertwined with the state interests and its security.

Therefore, the introduction of an e-visa system is an extremely important step that requires coordination of the efforts of the Ministry of Foreign Affairs, the Ministry of Internal Affairs, the Security Service, the Border Guard and other state bodies empowered to make decisions and influence the migration policy of the state.

The research identifies how the visa policy is regulated at the legislative level in Ukraine and in the Kingdom of Saudi Arabia and determined by what criteria the above countries identified a list of countries whose citizens are eligible to use the e-visa service.

Visa legislation has undergone significant changes in most countries over the last decade. First of all, it is related to the comprehensive introduction of electronic services and systems, which has necessitated the adaptation of national and international legislation. Secondly, the importance of the security factor is increasing every year, and every country seeks to have the most effective immigration control possible. Thirdly, the visa policy of the state has a great influence on its image, the number of visitors and, ultimately, the financial inflow into the national budget.

\subsection{Literature Review}

Research on the subject of visa policy of the state and introduction of the mechanism of electronic visa processing at the legislative level has been investigated by a number of authors both in Ukraine and in the near and far abroad. 
The theoretical aspects of the visa policies and the tendency of growing quantity of issuing visas worldwide and by countries were studied by Mathias Czaika and Eric Neumayer. In their scientific research they also studied the issue of the bilateral visa policy database covering up to 194 destination and 214 origin countries over the 1995 to 2013 period and provided the analysis of a visa restriction by a destination country (Czaika \& Neumayer, 2017).

Regarding Ukrainian researchers, attention should be paid to the fact that issues of migration law, visa policy and legislative regulation of visa issues in the EU and Ukraine have been actively studied in the scientific community. Y. Solomko in the research 'Status of implementation of electronic services' (2018) studied the aspects of implementation e-Visas as a part of e-governance, the Conceptual-categorical apparatus in the Sphere of visa liberalization was studied by G. Onishchenko (2016).

It was important to get acquainted with the works and documents of legal regulation of visa policy in the EU, since Ukrainian migration and visa law is focused on EU legislation in many matters, especially after liberalization of the visa regime between them. M. Hobolth in his research studied the similarities and differences in European visa practices (2010), F. Infantino studied the impact of Schengen visa policy on the countries with which it borders (2019), Perrine Dumas and Iris Goldner Lang studied the European Neighbourhood Policy, including the study of Ukrainian legislation and the migration issues related with the theme of research (2015). Given the course of Ukraine towards the implementation of EU legislation, it was important to familiarize the study of the visa policies by the European Commission (ANNEX to the Commission Decision No. C, 2010).

The importance of introduction of the eVisa policy of Saudi Arabia was covered in scientific work 'Virtual consulate primer: how to design and implement an e-Visa programme: partnership-based e-Governance innovations from Armenia and Saudi Arabia' (UNDP \& HPC, 2005). The problems of the visa policy of the Persian Gulf countries and related migration risks, including as a result of visa liberalization, were investigated be Hélène Thiollet in research 'Immigrants, Markets, Brokers, and States: The Politics of Illiberal Migration Governance in the Arab Gulf' (2019).

Research on e-Visa policy is becoming very relevant and popular in almost all countries and regions of the world. In some regions, the topic of e-visas began be explored 5 or 10 years ago. Elizabeth Bazua Rendon studied the visa policy between the member countries of The North American Free Trade Agreement (2010). In the context of the development of African continent and the forecasting visa policies of its countries in the coming decades, of great importance is the publication of World Tourism Organization '2019 Visa Openness Report for Africa' (2019).

At this stage, the study of subject of electronic visas and its legal field is being actively studied in most countries of the world, including in the countries of Eastern Europe bordering Ukraine, as well as in countries bordering Saudi Arabia. In general, this topic remains not sufficiently studied in Ukraine and Saudi Arabia, especially in matters of legislative regulation of electronic visas.

The issue of implementation at the legislative level and effective activity of e-visa service has strategic importance for state policy, its security, competitiveness and attractiveness. Research institutes are actively exploring the legal bases of their countries in order to form theoretical bases that will have important practical applications. In this context, the timely study of the visa policy of the state for the formation of a national scientific school is very important.

In the next 5-10 years, e-visas will almost completely replace the visa application for obtaining short-term visas through diplomatic institutions. At the same time, the success of this type of replacement will depend on the following factors:

1) the perfection of the legal framework governing the country's visa and migration legislation;

2) information and digital policy of the state, including the legally stipulated conditions for the submission of visa applications, their processing and the terms of consideration;

3) legally binding conditions for visa fees and e -visa validity, which must be competitive with the visa systems of other countries.

\subsection{Purpose and Objectives of the Research}

The main purpose of the research is to compare the legal regulation and determine practical functioning of electronic visas in Ukraine and Saudi Arabia.

The main objectives of the study are: a) to determine the effectiveness of the current legislation of Ukraine and the 
Kingdom of Saudi Arabia in the field of electronic visas; b) to determine common and different features in the requirements for electronic visa, the terms of visa application, the cost of its registration; c) identify weaknesses in the legislation of both countries in the field of electronic visas registration and propose mechanisms for its improvement; d) to determine the risks and dangers for both countries that will arise the replacement of regular visas by electronic visas.

\subsection{Object and Subject of the Study}

After you have introduced the problem and have developed the background material, explain your approach to solving the problem. In empirical studies, this usually involves stating your hypotheses or specific question and describing how these were derived from theory or are logically connected to previous data and argumentation. Clearly develop the rationale for each. Also, if you have some hypotheses or questions that are central to your purpose and others that are secondary or exploratory, state this prioritization. Explain how the research design permits the inferences needed to examine the hypothesis or provide estimates in answer to the question.

\section{Research Methods}

In scientific research were used the following methods:

- data collection. This method included the collection of data from scientific sources on the extent of the study of the issues and scientific approaches, as well as the collection of data from the laws governing visa policy of Ukraine and the Kingdom of Saudi Arabia;

- analysis. This method consists of analyzing the information received, as well as conducting an analysis of the requirements for submission and the practical aspects of the electronic visa procedure. The analysis includes this process both by the authorities making the decision to issue or refuse to issue an e-visa, and by the applicant submitting the documents for the electronic visa;

- synthesis. This method involves combining the results obtained in the analysis into a regular sequence and conducting classification;

- causal-comparative. This type of analysis is intended to identify the cause and effect relationships between existing legislation and its practical implementation. In addition, it determines which regulations have a positive or negative impact on applicants' desire to use the e-visa service;

- analogies. This method is to draw analogies between substantially different e-visa procedures for obtaining a permit to enter Ukraine and the KSA;

- surveys. This method provides practical results on the topic under study. Over a period of 3 months, about 100 Saudi and 20 Ukrainian respondents were interviewed to identify the pros and cons of existing e-visa regulations in both countries;

- forecasting. This method is based on others and aims to determine the prospects for the development of visa legislation on the issue of electronic visas, and identifies what aspects through legislative loopholes and shortcomings can slow the development of e-visa service in both countries.

\section{Results and Discussion}

\subsection{Electronic Visa as a Type of Visa and its Theoretical Basis}

Each country typically has a multitude of categories of visas with various names.

In most countries, visas are divided by the following criteria:

-Type of visa:

a. Transit visas (Airside transit visa, Crew member, steward, or driver visa);

b. Short-term visas (Private visa, Tourist visa, Visa for medical reasons, Business visa, Athletic or artistic visa, Cultural exchange, Official visit etc.) Saudi Arabia also provides Pilgrimage visas (Haj Visa and Umrah Visa);

c. Long-term visas (Student visa, Immigration Visa, Worker Visa, Reunion family Visa (also called Spouse visa), Diplomatic visas (provided that there is no agreement on visa exemption for diplomatic and/or service passports between countries, such as between Ukraine and Saudi Arabia).

- Method of issue:

a. Ordinary visas (when visa applications are made at and collected from a consulate, embassy, or other diplomatic mission). It is often the case that the authorized Visa Centers are used to receive the package of documents and return the passports to applicants, including those in Ukraine and Saudi Arabia; 
b. Visas upon arrival (also called On-arrival visas). Some country provide issuing visas on their borders. This is distinct from visa-free entry, where no visa is required, as the visitor must still obtain the visa on arrival before proceeding to immigration control. Ukraine also used this method of issuing visas before the introduction of the electronic visa system;

c. Electronic visa (usually called e-Visa or eVisa). This type of visa is stored in a computer and is linked to the passport number so no label, sticker, or stamp is placed in the passport before travel. The application is done over the internet, and the receipt acts as a visa, which can be printed or stored on a mobile device. receiving an electronic visa does not require citizens to contact Embassies and Consulates and is usually in the area of responsibility of the visa department of the Ministry of Foreign Affairs.

In addition to the difference in the applying procedure between a regular visa and an electronic visa, the latter aims at obtaining a short-term visa (usually a one-time entry, which allows to stay in the country of visit for a period from 30 up to 90 days) and does not provide a possibility of applying for a residence permit in the country of visit. On the whole, the introduction of electronic visas is an important step in the expansion of state-owned electronic services and also helps to increase the number of visitors (primarily for tourism purposes). Due to the legislative regulation, this format of visa facilitation has almost no or no negative impact on national security, as migration risks are pre-determined by the competent authorities of the country.

\subsection{Legislation of Ukraine and the Kingdom of Saudi Arabia in the Field of Electronic Visas}

In Ukraine, visa policy is governed by the following laws and regulations:

- The law of Ukraine 'On the Legal Status of Foreigners and Stateless Persons' 2011 (Act 3773-VI);

- The law of Ukraine 'On Immigration' 2001 (Act 2491-III);

- Resolution of the Cabinet of Ministers of Ukraine 'On approval of rules of issuing visas for entry into Ukraine and transit passage through its territory' 2017 (Act 118);

- Joint Order of the Ministry of Foreign Affairs of Ukraine, the Ministry of Internal Affairs of Ukraine and the Security Service of Ukraine 'On approval of the Requirements for the organization of work on issuing visas for entry into Ukraine and transit passage through its territory' 2017 (Act 469/897/605);

- Order of the Ministry of Foreign Affairs of Ukraine 'On Approval of Requirements for Registration of Electronic Visas' 2017 (Act 558).

In Saudi Arabia visa policy is governed by the following laws and regulations:

- Supreme Royal Order 11/09/1371H (4/6/1952G) (Act 17 2/25/1337);

- Resolution of His Excellency the Minister of Hajj and Umrah 1/5/1441 (Act 410105143);

- Royal Decree 9/17/1440 (Act M/111);

- Royal Decree 5/1/1441 (Act M/2);

- Regulation of the Saudi Commission for Tourism \& National Heritage 2019 (Act 4800).

\subsection{The e-Visa Service in Ukraine and Kingdom of Saudi Arabia}

Ukraine has launched an electronic visa service on April $4^{\text {th }}$ of 2018 . At the time of its introduction, the e-Visa registration service fee was $\$ 65$ USD and could be used by citizens of 46 states, including Kingdom of Saudi Arabia nationals.

The list of countries, whose citizens are allowed to apply for electronic visas directly depends on the state's migration policy. Such a function did not extend to the list of countries identified in the Joint Order of the Ministry of Foreign Affairs of Ukraine, the Ministry of Internal Affairs of Ukraine and the Security Service of Ukraine, which states that the issuance of visas to the citizens of these countries is carried out by the foreign diplomatic institution of Ukraine in the country of temporary or permanent residence of the applicants after an individual interviewing a foreigner or stateless person with the competent authorities.

At the time of introduction of the electronic visa system, it was envisaged to issue an e-visa for a period of 30 days solely for the purpose of tourist C-06 (e) or business C-01 (e) purpose, however, in accordance with the Decree of the Ministry of Foreign Affairs of Ukraine 2018 (Act 525). This list has been expanded to include the following travel purposes: C-02 (e) Private; C-07 (e) - Medical treatment; C-09 (e) - Cultural, scientific, educational, sport activities; C-11 (e) - Mass Media staff visits.

According to the Resolution of the Cabinet of Ministers of Ukraine 2018 (Act 954), the e-Visa registration service fee is $\$ 85$ USD. Beginning from January 1, 2019 the list of countries whose citizens can visit Ukraine by 
electronic visa has been expanded to 52 .

Kingdom of Saudi Arabia launched both an Electronic visa and On-arrival visa on September $27^{\text {th }}$ of 2019 as a part of National strategy 'Vision-2030'. General Directorate of Passports indicated that at the first stage, citizens of 49 countries including Ukraine can obtain an electronic tourist visa through the online platform or apply for a visa through passport offices upon their arrival in the Kingdom. The tourist visa contains additional purpose of visit which consists of the next types of eVisa: Event, Family \& Relatives, Leisure, Umrah.

General Directorate of Passports indicated that upon arrival in the Kingdom, a tourist visa could be issued through self-service devices, through smart phones or through visa issuance offices at the entry ports in the main airports of the Kingdom.

Both types of visa allow for foreign citizen from aforementioned countries to enter the Kingdom for multiple times, the visa's validity expires within one year from the date of its issuance provided that the tourist can reside in the Kingdom for a maximum period of 90 days during one year. It was determined that visa fee would be 440 saudi riyal (\$ 117 USD), including medical insurance. On January $2^{\text {nd }}$ of 2020 the General Authority for Tourism and National Heritage affirmed that citizens of other nationalities who have valid and at least once used multiple visas to the United States of America, the United Kingdom or the European (Schengen) visa can enter the Kingdom of Saudi Arabia and obtain a visitor visa through airports of the Kingdom.

Having analyzed the visa policy in the field of regulation and registration of electronic visas in Ukraine and in the Kingdom of Saudi Arabia, we must admit that the approach to the migration component is similar. At the same time, the validity of an e-visa in Ukraine and Kingdom of Saudi Arabia are different: in Ukraine only a single e-visa is issued with a validity of up to 30 days, while in Saudi Arabia it is possible to obtain an annual multiple e-visa with the duration of stay up to 90 days. The cost of issuing an electronic visa in Ukraine is slightly lower than in Saudi Arabia (\$85 USD against \$117 USD.). At the same time, in Saudi Arabia, compulsory insurance is immediately included in the visa fee, while travelers to Ukraine must independently purchase an insurance policy that meets the necessary requirements.

\subsection{Practical Functioning of Service of Issuing Electronic Visa in Ukraine and Saudi Arabia}

\subsubsection{Practical Functioning of Applying for Electronic Visa in Ukraine}

Citizens of the following countries are eligible to apply for an electronic visa to enter Ukraine (MFA):

Australia, Bahamas, Bahrain, Barbados, Belize, Bolivia, Bhutan, Cambodia, China, Colombia, Costa Rica, Dominica, Dominican Republic, Ecuador, El Salvador, Fiji, Grenada, Guatemala, Haiti, Honduras, Indonesia, Jamaica, Kiribati, Kuwait, Laos, Malaysia, Maldives, Marshall Islands, Mauritius, Mexico, Micronesia, Myanmar, Nauru, Nepal, New Zealand, Nicaragua, Oman, Palau, Peru, Saint Lucia, Saint Vincent and the Grenadines, Samoa, Solomon Islands, Saudi Arabia, Seychelles, Singapore, Suriname, Thailand, Timor-Leste, Trinidad and Tobago, Vanuatu.

Applicants are offered 4 languages on the e-visa website: Ukrainian, English, Arabic and Spanish.

Visa application form must be submitted no earlier than three months and no later than 10 working days before the scheduled trip.

To apply for an e-Visa to Ukraine the applicant must:

1) Register on the MFA web platform (MFA).

2) Fill the online visa application form.

3) Upload copies of necessary documents: photo; passport; health insurance policy (30.000 Euro coverage); proof of sufficient funds; document confirming the purpose of the visit.

4) Pay the fee (\$85 USD) online by MasterCard/Visa card.

When the submitted documents are examined, an applicant receives an issued e-Visa or visa refusal letter by e-mail (in PDF format).

All applicants should submit their printed e-Visas (along with their valid travel documents) to Ukraine's State Border Guard Service officers when entering Ukraine. In the process of submitting documents, the service provides the possibility to save the data filled in by the applicant and in the absence of certain supporting documents to download them subsequently.

The uploaded photo of the applicant must comply with ICAO international standards (ICAO), otherwise a refusal will be received. 
Visa application form is composed from 27 points to be filled by the applicant (table 1):

Table 1. The main points of the visa application form (Ukraine)

\begin{tabular}{cl}
\hline $\begin{array}{c}\text { No. } \\
\text { point }\end{array}$ & \\
\hline & General information \\
1 & Surname(s) / Family name(s) (as indicated in the passport document) \\
2 & Surname(s) / Family name(s) at birth / Previous surname(s)/family name(s) \\
3 & Name(s) / Given name(s) (as indicated in the passport document) \\
4 & Date of birth (day-month-year) \\
5 & Place of birth \\
6 & Country of birth \\
7 & Current nationality / citizenship (as indicated in the passport document) \\
8 & Sex \\
9 & Marital status \\
& Documents certifying the identity of the applicant \\
10 & National identity/personal number (if applicable) \\
11 & Type of the passport/travel document \\
12 & Passport document's series/ number \\
13 & Issue date \\
14 & Valid until \\
15 & Issued by / authority (as indicated in the passport document) \\
& Place of residence of the applicant \\
16 & Applicant's postal address and email address \\
17 & Telephone number(s) including international dial codes \\
18 & Purpose of travel/stay \\
21 & Intended date(s) of stay in Ukraine \\
21 & Previous Ukrainian visas (issued during the past three years) \\
\hline & Entry to Ukraine's temporarily occupied territories of the Autonomous \\
& Application filled: Place and Date \\
\hline
\end{tabular}

After filling all the necessary information, uploading a personal photo and copies of Passport document, medical insurance policy, a document confirming the applicant's sufficient financial funds and a document confirming the purpose of visit the visa fee is paid and the application review period begins.

3.4.2 Practical Functioning of Applying for Electronic Visa in Saudi Arabia

Citizens of the following countries have the right to apply for an electronic visa to enter Saudi Arabia (OTW Saudi):

North America: Canada, USA;

Europe: Andorra, Austria, Belgium, Bulgaria, Croatia, Cyprus, Czech Republic, Denmark, Estonia, Finland, France, Germany, Greece, Holland, Hungary, Iceland, Ireland, Italy, Latvia, Liechtenstein, Lithuania, Luxembourg, Malta, Monaco, Montenegro, Norway, Poland, Portugal, Romania, Russia, San Marino, Slovakia, 
Slovenia, Spain, Sweden, Switzerland, Ukraine, United Kingdom;

Asia: Brunei, China (including Hong Kong and Macau), Japan, Kazakhstan, Malaysia, Singapore, South Korea;

Oceania: Australia, New Zealand.

Applicants are offered 2 languages on the e-visa website: English and Chinese.

To apply for an eVisa to Saudi Arabia the applicant must:

1) Register on the web platform of The official tourism website of Saudi Arabia.

After registration is completed applicant must sign in and choose while he is applying for individual type of eVisa or group type of eVisa. There is also the option of completing a visa application on behalf of someone else.

2) Fill the online visa application form.

3) Upload copies of necessary documents: only photo required.

4) Agree the terms of obligatory medical insurance (There are a list of the companies that are approved and certified in Saudi Arabia. Applicant does not have an option to specify the name of company he/she would prefer to choose). The insurance price including VAT is 140 SAR (\$37.33 USD) and it covers only emergency cases. Without the agreement the applicant will not proceed to the next page.

5) Read and Agree with the rules, laws, prohibitions and restrictions applicable to visitors to the Kingdom.

6) Review the information filled in the application form and choose method of payment (Visa/Master card, Union Pay, American Express or Apple pay).

7) Pay totally 463.44 SAR (\$123.58). The payment consists of the eVisa Fee - 300.00 SAR (\$85 USD), Insurance Fee - 133.00 SAR (\$35.46 USD), VAT 5\% - 22.00 SAR (\$5.86 USD) and Associated transaction Fee 8.44 SAR (\$2.25 USD).

Visa application form is composed from 31 points to be filled by the applicant (table 2):

Table 2. The main points of the visa application form (Saudi Arabia)

\begin{tabular}{cl}
\hline $\begin{array}{c}\text { No. } \\
\text { point }\end{array}$ & \\
\hline & General information \\
1 & Country of Nationality* \\
2 & First Name or Given Name (English)* \\
3 & Father Name or Middle Name (English) 'Optional, If available in passport' \\
4 & Last Name or Family Name (English)* \\
5 & Gender* \\
6 & Marital Status* \\
7 & Date of Birth* \\
8 & Country of Birth* \\
9 & City of Birth* \\
10 & Profession* (In case of minor indicate 'None') \\
& Current Residence Address \\
11 & Country* \\
12 & City* \\
13 & Zip/Postal Code \\
& Document information \\
14 & Passport Type* \\
15 & Passport No** \\
16 & Passport Issue Place (Country or City)* \\
\hline
\end{tabular}




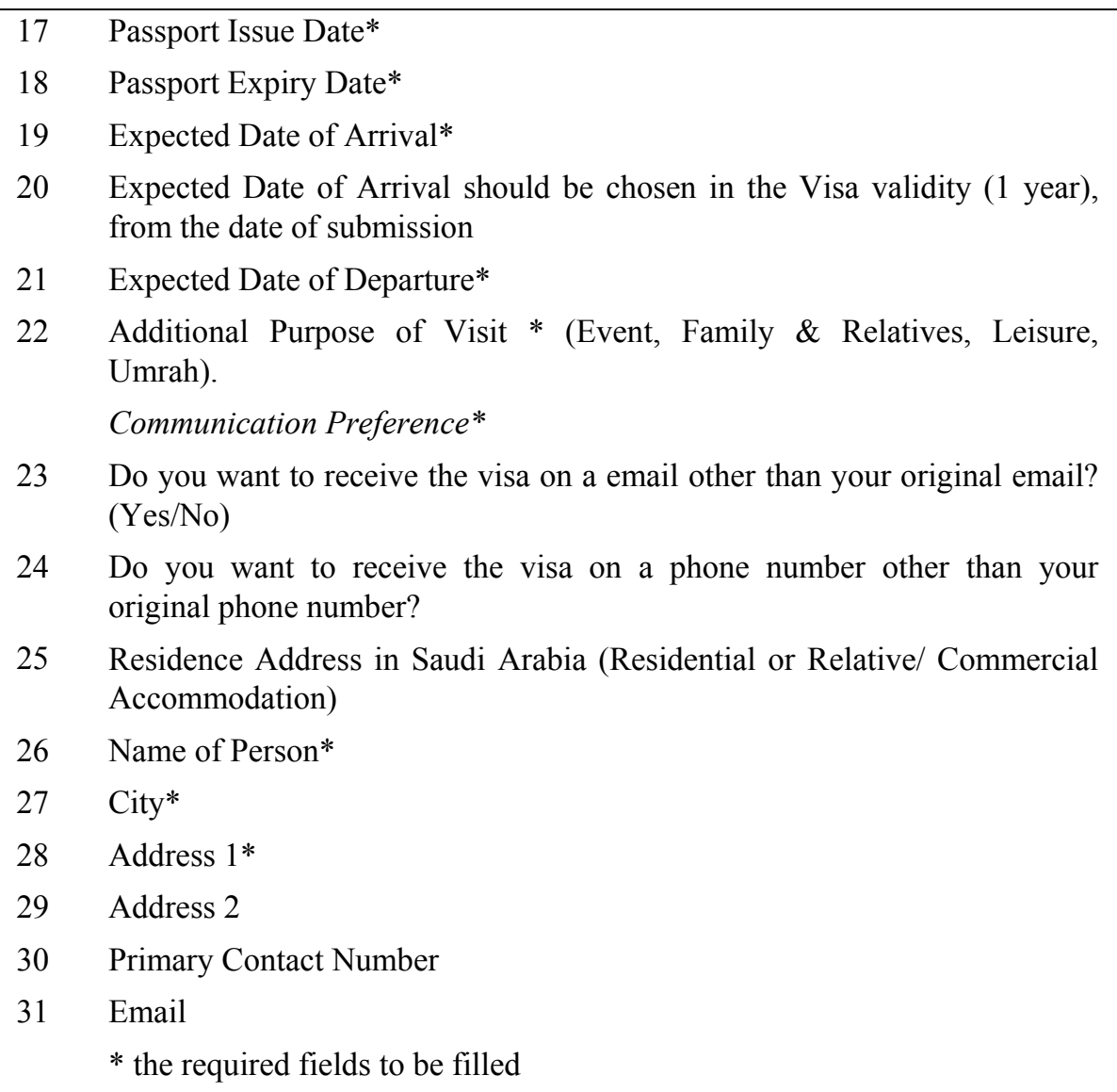

In general, the registration procedure on the online platform for issuing an electronic visa in Saudi Arabia is similar to the Ukrainian one.

At the same time, there are differences in the following issues:

1) The visa fee for issuing an e-visa to Ukraine is $\$ 85$ and does not include insurance, while the visa fee for issuing an e-visa to the Kingdom of Saudi Arabia includes health insurance and costs a total of \$ 123.58.

2) A visa application for an e-visa to Ukraine is considered to be 9 working days, whereas an e-visa to Saudi Arabia is usually issued within 4 days (very often almost immediately after the submission of a visa application by applicant and successful payment of visa fee).

3) E-visa into Ukraine is issued as a single, one-entry visa with allowed duration of stay up to 30 days, whereas an eVisa to Saudi Arabia is issued as one-year, multiple entry visa with allowed duration of stay up to 90 days.

4) The electronic visa to Ukraine specifies the purpose of the trip in more detail, while regardless of the purpose of the trip to Saudi Arabia, all e-visas are considered as tourist visas.

5) In order to apply for e-visa to Ukraine it is necessary to upload more quantity of documents, whereas application form of e-visa to Saudi Arabia requires from applicant to upload personal photo only.

When comparing the two online platforms, it should be noted that there are more requirements for obtaining an e-visa to Ukraine, which is reflected in the legislation in particular.

\subsection{Survey Regarding to the Electronic Visa Services Provided by Ukrainian and Saudi Arabian Government}

Over a period of 3 months, about 100 Saudi and 20 Ukrainian respondents were interviewed to identify the pros and cons of existing e-visa regulations in both countries.

The main purpose of questioning was to determine how existing legislation affects Saudi and Ukrainian citizens' satisfaction with the e-visa service of both countries (tables 3, 4). 
Table 3. Survey of subjects of the Kingdom of Saudi Arabia about the e-Visa service provided by Ukrainian government

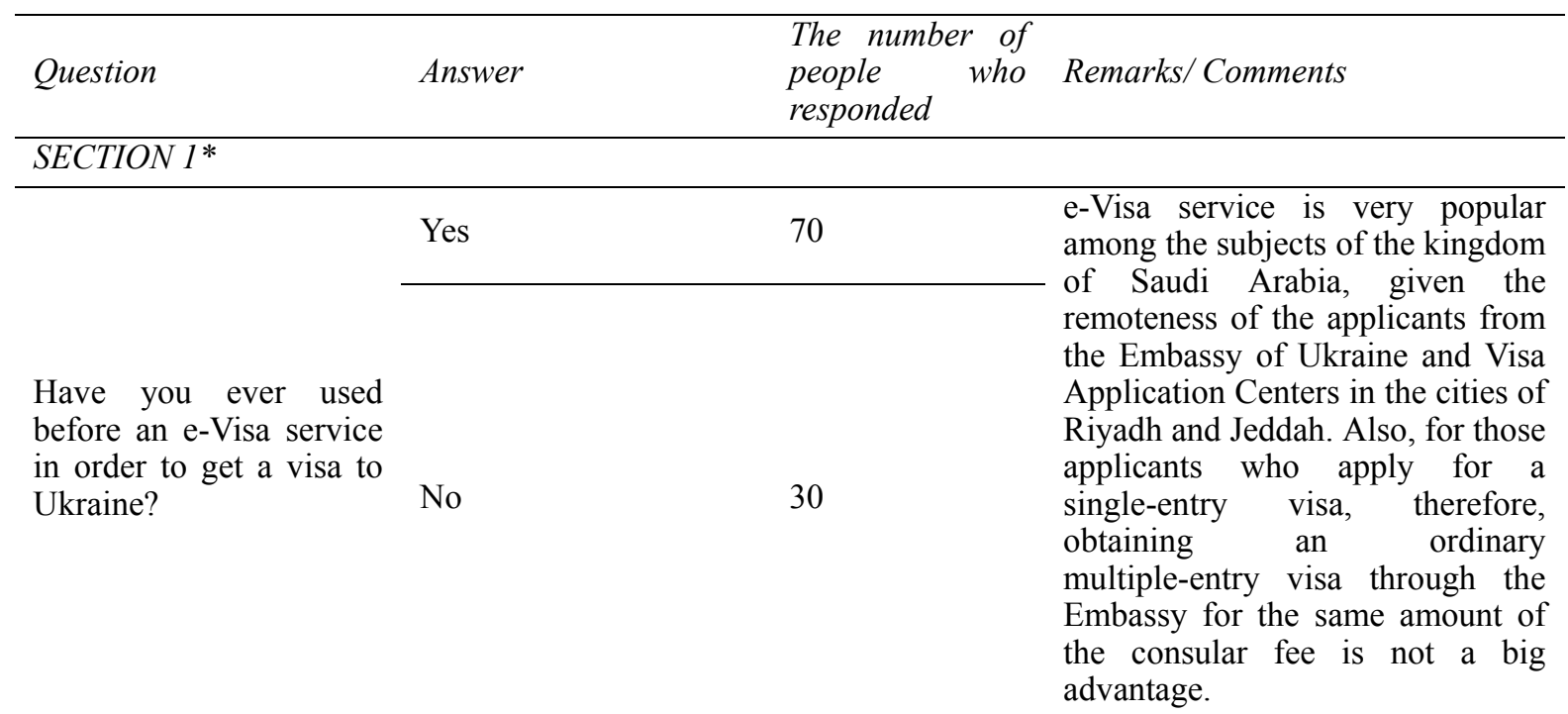

What is the main reason of the decision to apply of e-Visa?

No need to submit documents personally to the Embassy or Visa 92 Center
Almost all answered the same way. 5 of respondents answered that they wanted to try this service, 3 of them chose this service by accident, wishing to apply for a regular visa through the Visa Center.

According to some applicants, the required number of uploaded documents is too large. The key problem is the long period of consideration of the visa application (up to 9 working days), which, taking into account weekends and holidays, can reach up to 15 days.

The procedure for obtaining a regular visa through the Embassy for the same amount of visa fee and with the option of obtaining a multiple annual visa takes up to 5 business days, and in the autumn-spring period it is often issued within 2-3 business days.

\begin{tabular}{|c|c|c|c|}
\hline \multirow{4}{*}{$\begin{array}{l}\text { Generally, what is your } \\
\text { opinion about the } \\
\text { possibility of applying } \\
\text { for visa online? }\end{array}$} & Very positive & 16 & \\
\hline & Positive & 41 & \\
\hline & $\begin{array}{l}\text { There are some pluses } \\
\text { and some minuses of } \\
\text { applying for visa online }\end{array}$ & 25 & \\
\hline & It's difficult to answer & 18 & \\
\hline \multicolumn{4}{|l|}{ SECTION 2** } \\
\hline \multirow{3}{*}{$\begin{array}{l}\text { Did you get an e-visa the } \\
\text { previous time you } \\
\text { applied? }\end{array}$} & $\begin{array}{l}\text { Yes, without any } \\
\text { problems }\end{array}$ & 51 & \multirow{3}{*}{$\begin{array}{l}\text { There are a certain number of } \\
\text { applicants who could not comply } \\
\text { with the necessary requirements } \\
\text { regarding the content and format } \\
\text { of the uploaded documents. }\end{array}$} \\
\hline & $\begin{array}{l}\text { Yes, but my visa } \\
\text { application was sent to } \\
\text { me for revision. }\end{array}$ & 16 & \\
\hline & No, I got a refuse & 3 & \\
\hline
\end{tabular}




\begin{tabular}{|c|c|c|c|}
\hline \multirow{3}{*}{$\begin{array}{l}\text { Were you satisfied with } \\
\text { the e-visa registration } \\
\text { service }\end{array}$} & Yes & 52 & \multirow{3}{*}{$\begin{array}{l}\text { In general, for most applicants } \\
\text { who have already applied for an } \\
\text { e-visa, the service is simple and } \\
\text { convenient. }\end{array}$} \\
\hline & No & 11 & \\
\hline & It's difficult to answer & 7 & \\
\hline \multirow{4}{*}{$\begin{array}{l}\text { Would you apply for } \\
\text { e-Visa again? }\end{array}$} & Surely yes & 21 & \\
\hline & Probably yes & 28 & \\
\hline & Don't know & 12 & \\
\hline & No & 9 & \\
\hline \multirow{5}{*}{$\begin{array}{l}\text { What is the main minus } \\
\text { of the existing electronic } \\
\text { visa application system? }\end{array}$} & $\begin{array}{l}\text { The time of visa } \\
\text { processing is too long }\end{array}$ & 49 & \multirow{5}{*}{$\begin{array}{l}\text { The main dissatisfaction is caused } \\
\text { by the length of consideration of } \\
\text { the e-visa application, which, } \\
\text { given the mentality of citizens of } \\
\text { the Kingdom of Saudi Arabia to } \\
\text { apply shortly before the planned } \\
\text { trip, is a significant minus in } \\
\text { comparison with the procedure for } \\
\text { applying for a regular visa through } \\
\text { the Embassy. }\end{array}$} \\
\hline & $\begin{array}{l}\text { The requirements are } \\
\text { too strict/ It's difficult } \\
\text { to submit all required } \\
\text { documents }\end{array}$ & 6 & \\
\hline & $\begin{array}{l}\text { There is no possibility } \\
\text { to apply for multiple } \\
\text { entry e-Visa and no } \\
\text { possibility to apply for } \\
\text { duration of stay up to } \\
90 \text { days }\end{array}$ & 12 & \\
\hline & The visa fee is too high & 0 & \\
\hline & $\begin{array}{lll}\begin{array}{l}\text { Other/ } \\
\text { answer }\end{array} & \text { Difficult } & \text { to } \\
& & \end{array}$ & 3 & \\
\hline \multirow{5}{*}{$\begin{array}{l}\text { What was your purpose } \\
\text { of visit according to visa } \\
\text { application? }\end{array}$} & Tourism & 56 & \multirow{5}{*}{$\begin{array}{l}\text { The tourist purpose of the trip is } \\
\text { the most popular and has the } \\
\text { potential for slight growth in the } \\
\text { next few years. } \\
\text { Also, there is a growing trend of } \\
\text { trips for the purpose of medical } \\
\text { treatment. }\end{array}$} \\
\hline & Private visit & 1 & \\
\hline & Business visit & 7 & \\
\hline & Medical treatment & 3 & \\
\hline & Other/ I don't remember & 3 & \\
\hline
\end{tabular}

* All correspondents had already at least once applied for a e-Visa to Ukraine or were present at the time of the interview in the applicant's status.

** questions only for those, who have already applied before for e-Visa to Ukraine. 
Table 4. Survey of Ukrainian citizens about the eVisa service provided by Saudi government

\begin{tabular}{ccc}
\hline Question & The number of & Remarks/Comments \\
& people who \\
& responded
\end{tabular}

What is the main reason No need to submit of the decision to apply documents personally of eVisa? documents personally
to the Embassy or Visa Center.
Before introducing of eVisa services it was impossible to obtain tourist visa to the Kingdom of Saudi Arabia. Generally, the procedure of obtaining the visa for any purpose in the Embassies/Consulates of Saudi Arabia abroad was difficult. The decision was taken by Ministry of Foreign Affairs, so the features of diplomatic missions abroad was very truncated.

\begin{tabular}{lll}
\hline What caused the most $\begin{array}{l}\text { difficulties when } \\
\text { applying for an e-visa? }\end{array}$ & $\begin{array}{l}\text { There was no } \\
\text { difficulties }\end{array}$ & 18 \\
\cline { 2 - 2 } & $\begin{array}{l}\text { I met some difficulties } \\
\text { with filling the visa } \\
\text { application form on } \\
\text { online platform }\end{array}$ & 2 \\
\hline
\end{tabular}

\begin{tabular}{|c|c|c|c|}
\hline \multirow{2}{*}{$\begin{array}{l}\text { Generally, what is your } \\
\text { opinion about the } \\
\text { possibility of applying } \\
\text { for visa online? }\end{array}$} & Very positive & 15 & \multirow{2}{*}{$\begin{array}{l}\text { In this context, the key factor is the } \\
\text { lack of an alternative, which makes } \\
\text { eVisa a popular and effective tool } \\
\text { for visiting the Kingdom of Saudi } \\
\text { Arabia. }\end{array}$} \\
\hline & Positive & 5 & \\
\hline \multirow{3}{*}{$\begin{array}{l}\text { Would you apply for } \\
\text { e-Visa again? }\end{array}$} & Surely yes & 11 & \multirow{3}{*}{-} \\
\hline & Probably yes & 7 & \\
\hline & Don't know & 2 & \\
\hline \multirow[t]{4}{*}{$\begin{array}{l}\text { What is the main minus } \\
\text { of the existing } \\
\text { electronic visa } \\
\text { application system? }\end{array}$} & $\begin{array}{l}\text { The requirements are } \\
\text { too strict/ It's difficult } \\
\text { to fill all required } \\
\text { information }\end{array}$ & 2 & \multirow{4}{*}{$\begin{array}{l}\text { At the legislative level, the issue of } \\
\text { the maximum allowed period of } \\
\text { stay in the territory of the Kingdom } \\
\text { of Saudi Arabia has not been fully } \\
\text { resolved. }\end{array}$} \\
\hline & $\begin{array}{l}\text { There is no enough } \\
\text { information about the } \\
\text { legislation of eVisa }\end{array}$ & 9 & \\
\hline & The visa fee is too high & 2 & \\
\hline & $\begin{array}{l}\text { Other/ Difficult to } \\
\text { answer }\end{array}$ & 7 & \\
\hline \multirow{3}{*}{$\begin{array}{l}\text { What type of the } \\
\text { purpose you chose in } \\
\text { Tourist visa? }\end{array}$} & Tourism & 14 & \multirow{3}{*}{$\begin{array}{l}\text { After the introduction of the eVisa } \\
\text { service, Saudi Arabia becomes an } \\
\text { interesting tourists destination. } \\
\text { Also, the eVisa service has become } \\
\text { an excellent opportunity to apply } \\
\text { for a guest visa in a simplified form }\end{array}$} \\
\hline & Family \& Relatives & 6 & \\
\hline & Other & 0 & \\
\hline \multirow{3}{*}{$\begin{array}{l}\text { Would you prefer to } \\
\text { choose next time eVisa } \\
\text { or Visa upon-arrival? }\end{array}$} & eVisa & 19 & \multirow{3}{*}{$\begin{array}{l}\text { For Ukrainian citizens wishing to } \\
\text { visit Saudi Arabia, applying for an } \\
\text { e-Visa is a more affordable and } \\
\text { reliable option than obtaining a visa } \\
\text { upon arrival }\end{array}$} \\
\hline & Visa uppon-arrival & 0 & \\
\hline & $\begin{array}{l}\text { I don't know/ difficult } \\
\text { to answer }\end{array}$ & 1 & \\
\hline
\end{tabular}

*All correspondents had already at least once applied for a eVisa to the Kingdom of Saudi Arabia. 
On the basis of the answers, it was possible to identify common problematic aspects that, in the case of changes in the legislation on visa policy regulation in the country, could have a positive effect for both citizens using the e-visa service and the state itself. At the same time, the purpose of the survey was to find out why a particular citizen prefers an e-visa to a regular visa issued through the Embassy or Consulate and vice versa.

\subsection{Forecast Regarding to the Electronic Visa Services Provided by Ukraine and by Saudi Arabia}

Despite the fact that the electronic visa application service was launched in Ukraine only in 2018, and in Saudi Arabia in 2019, there is a confident understanding that this is the right strategy for the development of electronic services provided by states.

In order for countries, including Ukraine and Saudi Arabia, to be prepared for the challenges and threats that they will face in matters of security, migration and border control, decisive measures must be taken at the legislative level.

Given the globalization aspects, countries in the near future will simplify visa regimes, while introducing controlled visa-free regimes requiring an applicant who wants to visit the country to register in advance in a special electronic service and receive authorization to enter the country.

Legislative mechanisms for control of the above areas already exist in some countries. For example, in USA there is a service of Electronic System for Travel Authorization (ESTA) which is an automated system that determines the eligibility of visitors to travel to the United States under the Visa Waiver Program (VWP). Authorization via ESTA does not determine whether a traveler is admissible to the United States. U.S. Customs and Border Protection officers determine admissibility upon travelers' arrival. The ESTA application collects biographic information and answers to VWP eligibility questions. ESTA applications may be submitted at any time prior to travel, though it is recommended that travelers apply as soon as they begin preparing travel plans or prior to purchasing airline tickets (DHS).

In Canada there is a service of An Electronic Travel Authorization (eTA) which is an entry requirement for visa-exempt foreign nationals travelling to Canada by air. An eTA is electronically linked to a traveller's passport. It is valid for up to five years or until the passport expires, whichever comes first (GCOW).

In September 2018, the Council and the European Parliament adopted two legislative acts, a Regulation establishing the European Travel Information and Authorisation System ('ETIAS') (Act 1240) and an amendment of the Europol Regulation for the purpose of establishing ETIAS (Act 1241). The introduction of these services is planned in 2021.

ETIAS will be an electronic authorisation system allowing visa-free nationals to board a carrier to travel to the Schengen Zone. The difference between an ETIAS authorisation and a Schengen visa is that the process of the former is automated and centralized across the Schengen Area whereas a European visa is processed on a case-by-case basis by the visa officials of each Member State. The ETIAS visa will be similar to the ESTA of the USA or the eTA of Canada.

Therefore, given that the legislation of Ukraine on visa and migration policy is largely in line with the legislation of the EU and the Schengen countries, and the law of Saudi Arabia correlates with the legislation of the Gulf Cooperation Council, it is likely that in the future there will be a gradual facilitation of visa regimes at the same time as the development of national visa authorization programs similar in their features and forms to ESTA, eTA and ETIAS.

\section{Conclusions}

The scientific research provided conclusive evidence that the issue of implementation at the legislative level and effective activity of e-visa service has strategic importance for state policy, its security, competitiveness and attractiveness.

At the same time, it was determined that the field of legislation in the regulation of e-visas in many countries is at the initial level and requires constant improvement. It was determined that in the field of scientific research the largest number of scientific works is related to the visa policy of the EU, USA, Canada, and the topic of visa policy of Ukraine and Saudi Arabia is almost unexplored, especially in the issue of electronic visas

The hypothesis put forward regarding the fact that in the next 5-10 years, e-visas will almost completely replace the visa application for obtaining short-term visas through diplomatic institutions, including the results of a survey of such objective factors as the introduction and development of electronic services in general at the state level. At the same time, it was revealed that this required the creation of a more simplified and faster way to obtain an e-visa, while not losing ground in matters of state security and migration. 
Also, in the course of the study, it was possible to determine that the experience of implementing controlled visa-free travel through the creation of national electronic authorization systems has a great future, and the successful experience of such control systems in the United States and Canada can be useful for other states, including Ukraine and Saudi Arabia.

As for the comparison of the legal regulation and the practical functioning of electronic visas in Ukraine and Saudi Arabia, in the course of research it was possible to establish that:

1) service of electronic visas in Ukraine was launched one and a half years earlier than in Saudi Arabia, which enabled her to secure more completely the situation and take into account the nuances of the legislative level;

2) the amount of the visa fee for applying for an electronic visa established by Ukraine and Saudi Arabia is acceptable for most applicants, although in comparison with a visa-free or one-time electronic authorization fee for several years, these amounts are large;

3) for a successful existence and a competitive advantage over a regular visa, an electronic visa should be issued in a shorter time period (up to 5 working days, the best option in 3 days);

4) Saudi Arabia tied the mandatory purchase of health insurance to an electronic visa, which on the one hand is convenient for the applicant, and on the other hand brings money to the country's budget;

5) the possibility of obtaining a multiple entry visa for 90 days is a more attractive option for those wishing to visit the country;

6) electronic services are the future of the development of states, so the introduction of electronic authorization systems at the national and regional levels would be a big plus for both Ukraine and Saudi Arabia;

7) the number of issued electronic visas in the foreseeable future will far exceed the number of ordinary short-term visas issued by the Embassy or Consulate. The issuance of long-term visas electronically is unlikely, as this type of visa is associated with obtaining a residence permit in destination country, therefore, the option of studying visa applications by the embassy and consulate is more acceptable.

\section{Acknowledgments}

This research was conducted as part of a state program "Problems of the formation and implementation of state policy in the field of information security of Ukraine: theory and practice" and was supported in parts by Constitutional and Administrative Law Department National Aviation University research work "Ensuring the Constitutional Rights of Citizens in the Context of the Conventional Obligations of Ukraine" (State Registration No. 0119U103091).

\section{Competing Interest}

The authors declare no competing interest.

\section{Ethical Approval and Consent to Participate}

The Majmaah University for Research Ethics Committee (MUREC) (HA-01-R-008) has reviewed the application referred to in this paper, whose ethical endeavor has been approved under Ethics Number: Oct.29/COM-2019/6.

\section{Availability of Data and Materials}

The datasets used and analyzed during the current study are available from the corresponding authors on reasonable request.

\section{References}

Czaika, M., \& Neumayer, E. (2017). Visa Restrictions and Economic Globalisation. Applied Geography, 84, 75-82. Retrieved from https://ssrn.com/abstract $=3198515$

European Commission. (2019). ANNEX to the Commission Decision No. C(2019) 3464 final. Brussels. Retrieved from

https://ec.europa.eu/home-affairs/sites/homeaffairs/files/what-we-do/policies/borders-and-visas/visa-policy/ docs/20140709_visa_code_handbook_consolidated_en.pdf

Hobolth, M. (2010). Wanted and unwanted travellers: explaining similarities and differences in European visa practices. Presented at the Insiders and outsiders: Globalisation, citizenship and the future of the EU, London, GB. Retrieved from http://personal.lse.ac.uk/hobolth/doc/JMCE_2010_Hobolth.pdf

Infantino, F. (2019). Schengen visa implementation and transnational policymaking: bordering Europe. New 
York: $\quad$ Palgrave $\quad$ Macmillan. $\quad$ Retrieved from https://public.ebookcentral.proquest.com/choice/publicfullrecord.aspx?p=5683634

Ministry of Foreign Affairs of Ukraine. (2019). e-Visa. Retrieved from https://mfa.gov.ua/en/consular-affairs/entry-and-stay-foreigners-ukraine/e-visa

Ministry of Foreign Affairs of Ukraine. (2020). MFA web-platform for applying for e-Visa. Retrieved from https://evisa.mfa.gov.ua/

Official tourism website of Saudi Arabia. (2020). What is the Saudi eVisa. Retrieved from https://visa.visitsaudi.com/

Official website of the Department of Homeland Security U.S. (2019, December). Customs and Border Protection. Electronic System for Travel Authorization. Retrieved from https://www.cbp.gov/travel/international-visitors/esta

Onishchenko, G. V. (2016). Conceptual-categorical apparatus in the Sphere of visa liberalization. Newsletter of the Ministry of Justice of Ukraine, 12(182), 16-19. Retrieved from http://irbis-nbuv.gov.ua/cgi-bin/irbis_nbuv/cgiirbis_64.exe?C21COM=2\&I21DBN=UJRN\&P21DBN=UJR N\&IMAGE_FILE_DOWNLOAD=1\&Image_file_name=PDF/bmju_2016_12_10.pdf

Perrine, D., \& Iris, G. L. (2015). EU Mobility Regimes and Visa Policy Towards ENP Countries. Robert Schuman Centre for Advanced Studies.

Rendon, E. B. (2010). Visas Under NAFTA for Mexican and Canadian Citizens: The Increasing Restrictions on the E-visa Application Process for Mexican Nationals and the Lack of Remedies Against Arbitrary E-visa Denials (Doctoral dissertation, University of Arizona).

Solomko, Y. I. (2018). Status of implementation of electronic services: results of realization of the development. Theory and Practice of Public Administration, 3(62), 1-8. Retrieved from http://www.kbuapa.kharkov.ua/e-book/tpdu/2018-3/doc/1/1_14.pdf

The Government of Canada's official website. (2020, March). Electronic Travel Authorization (eTA). Retrieved from https://www.canada.ca/en/immigration-refugees-citizenship/services/visit-canada/eta.html?utm_source=part ner-eng\&utm_medium=website\&utm_campaign=eta

Thiollet, H. (2019). Immigrants, Markets, Brokers, and States: The Politics of Illiberal Migration Governance in the Arab Gulf. Amsterdam: International Migration Institute. Retrieved from https://hal.archives-ouvertes.fr/hal-02362910v2/document

United Nations Development Programme, \& Hewlett-Packard Company. (2005). Virtual consulate primer: how to design and implement an e-Visa programme : partnership-based e-Governance innovations from Armenia and Saudi Arabia. Bratislava: UNDP Europe and the Commonwealth of Independent States. Retrieved from https://www.un.am/up/library/Design_Implement_e-Visa\%20Programme_eng.pdf

Visa-Guides. (2020). ICAO photo requirements. Retrieved from https://visa-guides.com/ukraine/

World Tourism Organization. (2019). 2019 Visa Openness Report for Africa, UNWTO, Madrid. https://doi.org/10.18111/9789284421039

\section{Copyrights}

Copyright for this article is retained by the author(s), with first publication rights granted to the journal.

This is an open-access article distributed under the terms and conditions of the Creative Commons Attribution license (http://creativecommons.org/licenses/by/4.0/). 